
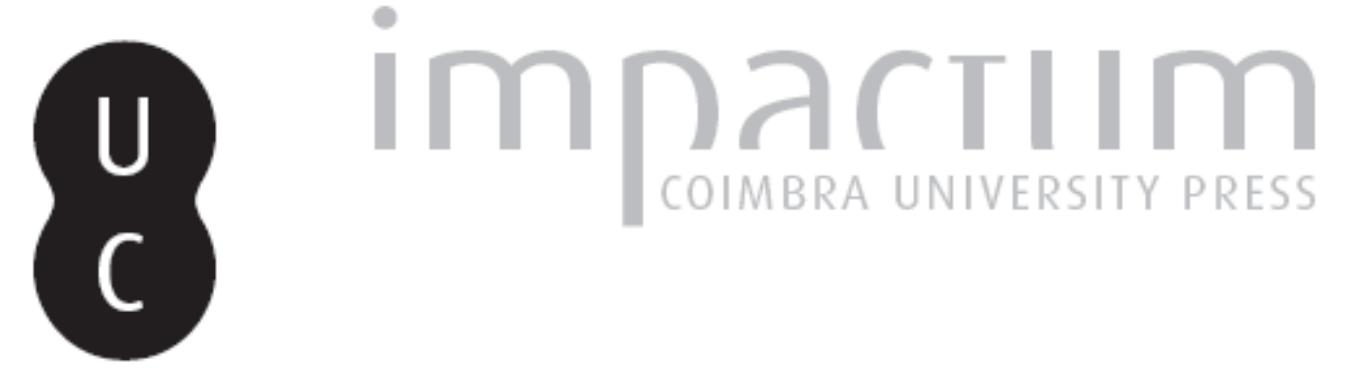

Causas do êxodo das minorias brancas da África Portuguesa: Angola e Moçambique (1974/1975)

\author{
Autor(es): $\quad$ Pimenta, Fernando Tavares \\ Publicado por: Imprensa da Universidade de Coimbra \\ URL \\ persistente: \\ URI:http://hdl.handle.net/10316.2/43241 \\ DOI: \\ DOI:https://doi.org/10.14195/0870-4147_48_5
}

Accessed : $\quad$ 26-Apr-2023 14:15:50

A navegação consulta e descarregamento dos títulos inseridos nas Bibliotecas Digitais UC Digitalis, UC Pombalina e UC Impactum, pressupõem a aceitação plena e sem reservas dos Termos e Condições de Uso destas Bibliotecas Digitais, disponíveis em https://digitalis.uc.pt/pt-pt/termos.

Conforme exposto nos referidos Termos e Condições de Uso, o descarregamento de títulos de acesso restrito requer uma licença válida de autorização devendo o utilizador aceder ao(s) documento(s) a partir de um endereço de IP da instituição detentora da supramencionada licença.

Ao utilizador é apenas permitido o descarregamento para uso pessoal, pelo que o emprego do(s) título(s) descarregado(s) para outro fim, designadamente comercial, carece de autorização do respetivo autor ou editor da obra.

Na medida em que todas as obras da UC Digitalis se encontram protegidas pelo Código do Direito de Autor e Direitos Conexos e demais legislação aplicável, toda a cópia, parcial ou total, deste documento, nos casos em que é legalmente admitida, deverá conter ou fazer-se acompanhar por este aviso.

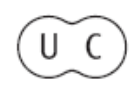




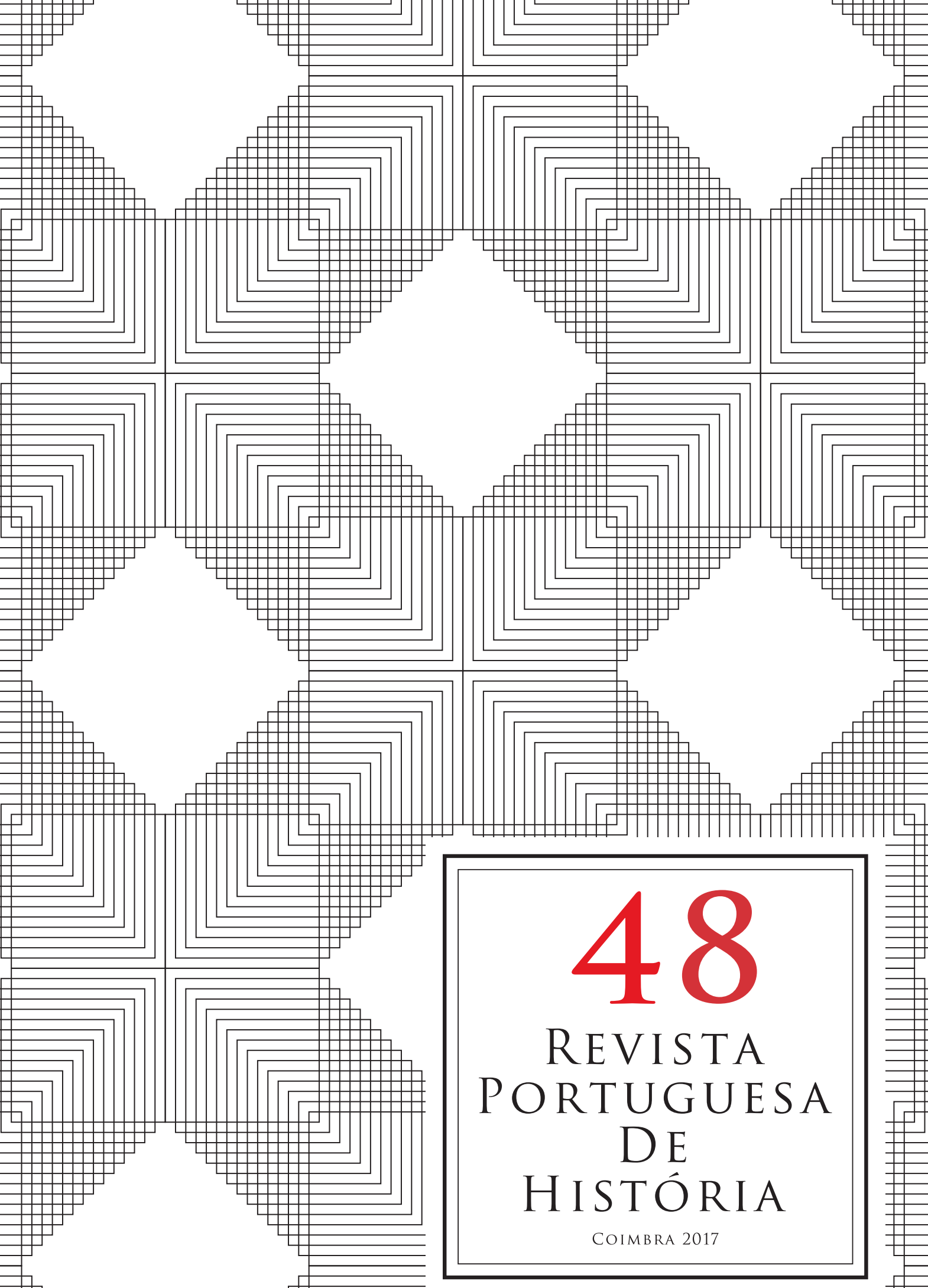




\title{
Causas do Êxodo das Minorias Brancas da África Portuguesa: Angola e Moçambique (1974/1975)
}

\section{The Exodus of White Settler Minorities from Portuguese Africa: Causes and Driving Forces (1974/1975)}

\author{
Fernando Tavares Pimenta \\ Centro de Estudos Interdisciplinares do Século XX da Universidade de Coimbra-CEIS20 \\ Instituto Português de Relações Internacionais da Universidade Nova de Lisboa \\ fernandopimenta_2000@yahoo.com
}

Texto recebido em/Text submitted on: 31/01/2017

Texto aprovado em/Text approved on: 19/04/2017

\begin{abstract}
Resumo:
Neste artigo analisamos as causas do êxodo das minorias brancas de Angola e de Moçambique durante o processo de descolonização português. O nosso objetivo é compreender o contexto histórico e político que enformou o êxodo dessas populações e, muito especialmente, demonstrar as razões que determinaram a fuga de cerca de meio milhão de colonos brancos para Portugal. Demonstramos assim que o êxodo da população branca foi o resultado de um conjunto de condicionantes - entre as quais a violência racial - e de opções políticas que não tiveram em devida consideração as especificidades sociais e culturais dessa população que, pela sua condição de estrato colonizador, não se situava no mesmo plano político da maioria colonizada.
\end{abstract}

\section{Palavras-Chave:}

Descolonização, Angola, Moçambique, Deslocados, Colonos Brancos.

\section{Abstract:}

In this article we analyze the causes of the white settlers' exodus from Angola and Mozambique during the Portuguese decolonization process. Our scope is to understand the historical and political context that shaped the settlers' exodus and, especially, to demonstrate the reasons that determined the flight of about half a million white refugees to Portugal. Thus, we will show that the exodus of the white population was the result of a set of constraints, including racial violence, and of political choices that did not take into account the social and cultural background of the white minority that, because of its colonial status, wasn't on the same political plane of the colonized majority.

Keywords:

Decolonization, Angola, Mozambique, Displaced Persons, White Settlers. 


\section{Causas do Êxodo das Minorias Brancas da África Portuguesa: Angola e Moçambique (1974/1975) ${ }^{1}$}

Neste artigo analisamos as causas do êxodo das minorias brancas das duas principais colónias portuguesas em África, ou seja, Angola e Moçambique. O nosso objetivo é compreender o contexto histórico e político que enformou o êxodo dessas populações e, muito especialmente, demonstrar as razões que determinaram a fuga de cerca de meio milhão de colonos brancos para a ainda metrópole durante a descolonização. Para o efeito, colocamos em perspetiva os processos de implosão das sociedades coloniais brancas da África Portuguesa, tendo em consideração o papel de vários agentes político-militares, nomeadamente do Estado Português, do Movimento das Forças Armadas (MFA), das guerrilhas africanas e dos movimentos políticos formados por brancos. Em termos cronológicos, focamos fundamentalmente o biénio relativo à derrocada do Império colonial, ou seja 1974/1975, ainda que o êxodo se tenha prolongado - mas de forma muito menos intensa - até ao final da década de 1970, em particular no caso de Moçambique.

Por sua vez, convém desde já salientar que o êxodo das minorias brancas das colónias portuguesas permanece um assunto pouco estudado ${ }^{2}$, inclusivamente pelos historiadores que se debruçaram sobre a descolonização portuguesa ${ }^{3}$, sendo na maior parte das vezes objeto de um exame sucinto e pouco problematizador dos factos históricos. A este respeito, constituem exceções os trabalhos pioneiros de Rita-Ferreira ${ }^{4}$, sobre o caso moçambicano, e de Rui Pena Pires ${ }^{5}$, cuja análise é essencialmente de cariz sociográfico. Falta, contudo, uma obra de carácter estrutural sobre o tema e que aborde a questão numa perspetiva comparada. De facto, o êxodo das minorias brancas deve ser entendido no contexto mais lato

\footnotetext{
${ }^{1}$ Agradeço à Dra. Guilhermina Mota a leitura e revisão do texto.

${ }^{2}$ Ao invés, o tema tem inspirado um conjunto apreciável de obras de ficção literária, bem como alguns trabalhos jornalísticos, com um significativo sucesso editorial. A título de exemplo veja-se: Dulce Maria Cardoso, O Retorno, Lisboa, Tinta da China, 2011.

${ }^{3}$ Sobre a descolonização portuguesa veja-se: Norrie Macqueen, A descolonização da África Portuguesa, Lisboa, Inquérito, 1998; António Costa Pinto, O fim do Império Português. A cena internacional, a guerra colonial e a descolonização, 1961-1975, Lisboa, Livros Horizonte, 2001; Tiago Moreira de Sá, Os Estados Unidos e a descolonização de Angola, Lisboa, Dom Quixote, 2011; Fernando Rosas, Pedro Aires de Oliveira e Mário Machaqueiro (ed.), O Adeus ao Império - 40 anos de descolonização, Lisboa, Nova Vega, 2015.

${ }^{4}$ A. Rita-Ferreira, "Moçambique post-25 de Abril. Causas do êxodo da população de origem europeia e asiática" in AA.VV., Moçambique: cultura e história de um país, Coimbra, Instituto de Antropologia, 1988, p. 121-169.

${ }^{5}$ Rui Pena Pires, Os retornados: um estudo sociográfico, Lisboa, IED, 1984.
} 
do fim dos Impérios coloniais europeus após 1945. Assim, a descolonização foi caracterizada por fluxos migratórios de deslocados coloniais para as respetivas metrópoles, particularmente nas colónias com maior número de brancos, as chamadas colónias de povoamento europeu. Para além das colónias portuguesas, esses fluxos de deslocados aconteceram, por exemplo, na Líbia italiana, no Congo belga, na Argélia francesa e, embora de forma mais gradual, no Quénia e na Rodésia do Sul (Zimbabwe), ambas colónias britânicas. Porém, o caso português foi proporcionalmente o mais significativo, pois o número de deslocados desembarcados na metrópole representou um quantitativo superior a $5 \%$ do total da população metropolitana. Em números absolutos, foi o segundo maior êxodo de brancos coloniais, apenas superado pelo mais de um milhão de franceses - os chamados pieds noirs - que abandonaram a Argélia em $1962^{6}$.

Dito isto, vejamos alguns dados demográficos sobre as populações brancas da África Portuguesa. Segundo o IV Recenseamento Geral da População ultramarina (1970), os brancos eram cerca de 290.000 em Angola e $162.967 \mathrm{em}$ Moçambique, constituindo respetivamente 5,1 \% e 2,0\% do total das populações dessas colónias. Os brancos angolanos constituíam então a segunda maior comunidade branca da África Austral, logo atrás da sul-africana e à frente da rodesiana (vide Quadro I). Em ambas as colónias portuguesas, o número de colonos continuou a aumentar de forma acelerada até 1974. Neste ano, os brancos seriam cerca de 335.000 em Angola e quase 200.000 em Moçambique. Este crescimento exponencial foi motivado pela política de fomento do povoamento branco com famílias provenientes da metrópole nos últimos anos da dominação colonial. O Estado Novo promoveu a instalação dessas famílias através da Junta de Povoamento do Ultramar e mediante a criação de um conjunto lato de novos colonatos, sobretudo nas melhores zonas agrícolas dos planaltos ou nos vales dos rios Cunene (Angola) e Limpopo (Moçambique) ${ }^{7}$.

\footnotetext{
${ }^{6}$ Charles-Robert Ageron et M. Michel (ed.), L'ère des décolonisations, Paris, Éditions Karthala, 1995.

${ }^{7}$ Ao longo do século XX, o ritmo de crescimento da população branca das duas colónias portuguesas não foi constante, tendo conhecido uma clara aceleração após 1945. Em Angola,

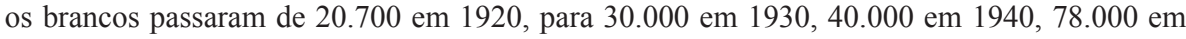
1950, 172.000 em 1960 e 290.000 em 1970. Em Moçambique, os brancos passaram de 17.842 em 1928, para 27.438 em 1940, 48.213 em 1950, 97.245 em 1960 e 162.967 em 1970. Sobre o povoamento branco da África Portuguesa veja-se: Cláudia Castelo, Passagens para África. O povoamento de Angola e de Moçambique com naturais da metrópole, Porto, Afrontamento, 2007; Fernando Tavares Pimenta, "Emigração madeirense para Angola e Moçambique (1930-1948). O Caso do Arquivo da Agência Ferraz", Islenha, n. ${ }^{\circ}$ 54, (2014), p. 93-110.
} 
Quadro I - Proporção da população branca em relação à população total de alguns territórios de povoamento europeu na África Austral em 1970 ${ }^{8}$

\begin{tabular}{|l|r|r|r|}
\hline \multicolumn{1}{|c|}{ Território } & \multicolumn{2}{|c|}{ População Branca } & \multicolumn{1}{c|}{ População Total } \\
\hline África do Sul & 3.773 .000 & $17,3 \%$ & 21.794 .000 \\
\hline Angola & 290.000 & $5,1 \%$ & 5.673 .046 \\
\hline Rodésia do Sul & 271.000 & $4,5 \%$ & 5.971 .000 \\
\hline Moçambique & 162.967 & $2,0 \%$ & 8.168 .933 \\
\hline
\end{tabular}

No entanto, este cenário de incremento demográfico inverteu-se logo após o 25 de Abril de 1974. No espaço de um ano e meio, a maioria dos colonos abandonou os dois territórios, gerando um fluxo de deslocados para a metrópole e, em grau menor, para os países vizinhos, nomeadamente para a África do Sul e a Rodésia. Um número apreciável de brancos, sobretudo provindos de Angola, foi para o Brasil. Não dispomos de valores exatos do número de deslocados nesses países, mas temos valores bastante aproximados relativamente ao êxodo para Portugal. Segundo o XII Recenseamento Geral da População Portuguesa (1981), o número de deslocados provenientes das colónias teria sido 471.427. Este valor não inclui os indivíduos que, tendo vindo inicialmente para a metrópole, depois emigraram para outros países, bem como os que faleceram nos anos anteriores à realização do recenseamento. De Angola teriam vindo 290.504 indivíduos, ou seja 61,6\% do total, e de Moçambique 158.945, ou seja 33,7\%. Um número diminuto de deslocados - cerca de 21.975 (4,7\%) proviria de outras colónias, nomeadamente da Guiné-Bissau, de Cabo Verde, de São Tomé e Príncipe e de Timor-Leste. Segundo o mesmo censo, quase dois terços dos deslocados teriam nascido em Portugal, mais precisamente 298.848 indivíduos (63,4\%). Ao invés, 164.346 (34,9\%) seriam naturais das ex-colónias e $8.233(1,7 \%)$ doutros países 9.

Uma vez chegados à metrópole, esses deslocados foram designados - sem distinção de naturalidade - de "retornados". Esta expressão está profundamente enraizada no léxico popular, em larga medida devido ao facto do governo

${ }^{8}$ Sobre os dados demográficos veja-se: Fernando Tavares Pimenta, Angola. Os Brancos e a Independência, Porto, Afrontamento, 2008, p. 461.

${ }^{9}$ Cf. Rui Pena Pires, "O regresso das colónias", in Francisco Bethencourt e Kirti Chauduri (ed.), História da Expansão Portuguesa, vol. V. Último Império e recentramento, 1930-1998, Lisboa, Temas e Debates, 2000. 
português ter criado um Instituto de Apoio ao Retorno de Nacionais (IARN), pelo decreto-lei n. ${ }^{\circ}$ 169/75, de 31 de março de 1975. Mas a utilização dessa expressão é contestada por muitos desses alegados "retornados", nomeadamente pelos que, não tendo nascido na metrópole, não conheciam outra "pátria" que não os territórios africanos, sendo que alguns nunca teriam vindo sequer à Europa. De facto, pelo menos um terço dos chamados "retornados" não nasceu em Portugal. Mais recentemente, tem-se generalizado, pelo menos na comunicação social, o termo "refugiados" para denominar os deslocados das colónias. No entanto, a classificação de "refugiados" coloca alguns problemas do ponto de vista do direito internacional, na medida em que os deslocados coloniais não reentram nos parâmetros definidos pela Convenção Relativa ao Estatuto dos Refugiados de $1951^{10}$. Com efeito, essa Convenção define os refugiados como pessoas que estão fora do seu país de nacionalidade "devido a fundados temores de perseguição". Ora, os deslocados das colónias movimentaram-se dentro do espaço imperial português, não atravessando por isso uma fronteira internacional, sendo nacionais e cidadãos de pleno direito do território de destino (Portugal). Por isso, aplica-se-lhes melhor a "classificação" de deslocados, ou seja pessoas que foram constrangidas a deixar as suas casas, mas que não cruzaram nenhuma fronteira internacional. Isto é, a deslocação - ou, por assim dizer, a fuga - aconteceu dentro do mesmo país. Contudo, importa salientar que o êxodo para a metrópole de cerca de meio milhão de pessoas provenientes das colónias africanas apresenta especificidades próprias dos fluxos de deslocados coloniais. Tal como nos casos dos belgas no Congo ou dos franceses na Argélia, o êxodo dos colonos portugueses implicou uma viagem sem retorno de milhares de quilómetros, entre dois continentes, da África para a Europa, para uma terra que, sendo formalmente parte do mesmo país, era muitas das vezes estranha a boa parte dos deslocados. E, cronologicamente, aconteceu no momento em que a construção imperial estava em processo de dissolução, com a consequente

\footnotetext{
${ }^{10}$ No termos da referida Convenção, o estatuto de refugiado é reservado à pessoa "que temendo ser perseguida por motivos de raça, religião, nacionalidade, grupo social ou opiniões políticas, se encontra fora do país de sua nacionalidade e que não pode ou, em virtude desse temor, não quer valer-se da protecção desse país, ou que, se não tem nacionalidade e se encontra fora do país no qual tinha sua residência habitual em consequência de tais acontecimentos, não pode ou, devido ao referido temor, não quer voltar a ele". A Convenção Relativa ao Estatuto dos Refugiados foi adotada em 28 de julho de 1951 pela Conferência das Nações Unidas de Plenipotenciários sobre o Estatuto dos Refugiados e Apátridas, convocada pela Resolução n. ${ }^{\circ} 429$ (V) da Assembleia Geral das Nações Unidas, de 14 de dezembro de 1950. Entrou em vigor em 22 de abril de 1954, de acordo com o artigo 43. Cf. Série Tratados da ONU, n. ${ }^{\circ}$ 2545, vol. 189, p. 137.
} 
amputação dos territórios de origem do fluxo migratório (as colónias) ao todo nacional, doravante adstrito à metrópole.

Por fim, refira-se que, concomitante ao êxodo dos brancos, ocorreu a fuga de um número significativo de mestiços e de africanos de origem indiana, bem como de alguns negros, que optaram por viver na metrópole ${ }^{11}$. Isto é, nem todos os deslocados eram brancos. E, no caso dos mestiços, a sua inserção na sociedade portuguesa foi facilitada pela Lei da Nacionalidade de 1975 (Decreto-lei n. ${ }^{\circ} 308$-A, de 24 de Junho de 1975), que estipulou a nacionalidade para os indivíduos provindos das (ainda) colónias portuguesas com base no critério da ascendência. Este critério excluiu a população negra, ou seja a grande maioria da população africana, mas permitiu o reconhecimento da nacionalidade portuguesa aos brancos e aos mestiços nascidos nas colónias, mas com ascendentes (pais, avós) portugueses. Além disso, os indianos residentes em Moçambique, mas naturais do Estado Português da Índia, também puderam manter a nacionalidade portuguesa. Não cabe no âmbito deste artigo fazer a história da fuga para a metrópole deste "subgrupo" mestiço (e indiano) no seio da população deslocada. Mas importa ressalvar a sua presença no quadro maior do êxodo dos deslocados coloniais para Portugal.

Feitas estas considerações, vejamos então o contexto histórico-político que enformou o êxodo das minorias brancas ${ }^{12}$.

\section{O 25 de Abril e a descolonização}

O 25 de Abril de 1974 criou as condições para a realização da descolonização do Império Africano. Inicialmente, o Estado Português deu a entender que o processo de descolonização obedeceria a princípios democráticos, garantindo a participação de todas as correntes políticas e estratos demográficos, incluindo os brancos. Esta pretensão foi alimentada principalmente pelo General António

${ }^{11}$ Stephen C. Lubkemann, "Unsettling the Metropole: Race and Settler Reincorporation in Postcolonial Portugal", in Caroline Elkins; Susan Pedersen (ed.), Settler Colonialism in the Twentieth Century: Projects, Practices, Legacies, New York, Routledge, 2005, p. 257-270.

${ }^{12}$ Utilizamos aqui a expressão "minorias brancas" com base num critério demográfico e com a ressalva de que estas não constituíam um bloco homogéneo do ponto de vista social, político e identitário. Porventura, alguns brancos não se viam a si próprios como tal; e outros casos havia em que mestiços, indianos e até alguns negros assimilados se consideravam a si mesmos brancos em virtude da enorme distância social que os separava da imensa maioria da população indígena. Sobre a questão das identidades sociais e políticas dos brancos coloniais veja-se: Fernando Tavares Pimenta, Angola no Percurso de um Nacionalista. Conversas com Adolfo Maria, Porto, Afrontamento, 2006, p. 7-27. 
de Spínola, na qualidade de Presidente da Junta de Salvação Nacional e, depois, de Presidente da República, mas também pelo I Governo Provisório liderado por Palma Carlos ${ }^{13}$.

No entanto, não havia consenso quanto à questão da descolonização no seio do novo poder revolucionário, havendo duas linhas antagónicas. Por um lado, havia a linha encabeçada por Spínola, que defendia a formação de uma federação de Estados entre a metrópole e as colónias, cuja aprovação seria submetida - por referendo - ao escrutínio das populações coloniais. Caso a solução federal fosse rejeitada nas urnas, as colónias acederiam à independência de forma pacífica e ordeira, após um período de transiçãa ${ }^{14}$. Por outro lado, havia uma linha mais "revolucionária", em maioria no seio do Movimento das Forças Armadas (MFA), e que contava com o apoio do General Costa Gomes e dos partidos de esquerda. Esta linha considerava que não havia condições objetivas para manter um exército em África a fim de assegurar a aplicação do plano de Spínola, nem isso era desejado pela maioria da população metropolitana, que estava cansada da guerra. Neste sentido, defendia a independência imediata das colónias mediante a transferência de poderes diretamente para as mãos das guerrilhas nacionalistas. Além disso, não atribuía qualquer legitimidade política a outros movimentos que não os que efetivamente tivessem feito a guerra. Isto é, considerava que a guerra tinha dado às guerrilhas uma espécie de legitimidade revolucionária que não era compartilhada por quaisquer outros movimentos políticos. De referir que este também era o entendimento da generalidade da comunidade internacional. Por isso, as grandes potências, a maioria dos países europeus, sobretudo os de orientação marxista e social-democrata, a Organização de Unidade Africana, o Comité de Descolonização das Nações Unidas defendiam a realização de uma descolonização rápida através da passagem de poderes para as guerrilhas nacionalistas que teriam, por assim dizer, uma legitimidade política acrescida face a quaisquer outros movimentos aparecidos depois do 25 de Abril de $1974^{15}$. E foi precisamente este entendimento que acabou por triunfar em setembro de $1974^{16}$.

${ }^{13}$ António de Spínola, Ao serviço de Portugal, Lisboa, Bertrand, 1976, p. 12-14 e 29-30.

${ }^{14}$ António de Spínola, Portugal e o futuro, Lisboa, Arcádia, 1974. Sobre o spinolismo veja-se: Francisco Bairrão Ruivo, Spinolismo: viragem política e movimentos sociais, Lisboa (Tese de doutoramento em História apresentada à FCSH), 2014.

${ }^{15}$ Pedro Aires Oliveira, "A descolonização portuguesa: o puzzle internacional” in Fernando Rosas, Mário Machaqueiro e Pedro Aires Oliveira (ed.), O Adeus ao Império. 40 anos de descolonização portuguesa, Lisboa, Nova Vega, 2015, p. 70-71.

${ }^{16}$ Fernando Tavares Pimenta, Portugal e o Século XX. Estado-Império e Descolonização, 1890-1975, Porto, Afrontamento, 2010, p. 135-139. 
De facto, a estratégia spinolista não logrou obter resultados satisfatórios, na medida em que as tentativas de conversações com as guerrilhas falharam por completo, à exceção do caso da UNITA, que assinou umas tréguas com os portugueses em 17 de junho de 1974. Para além disso, em 9 de julho de 1974, Palma Carlos resignou ao cargo de Primeiro-Ministro, na sequência da rejeição pelo Governo Provisório da sua proposta para avançar com as eleições presidenciais ainda em 1974. A Palma Carlos sucedeu um governo liderado por Vasco Gonçalves, um militar de esquerda, próximo do PCP, que acentuou a pressão para uma mudança da política colonial. Pressionado pelo governo, pelos partidos de esquerda, pelo MFA e por uma parte significativa da comunidade internacional, que via o Império Português como uma realidade desfasada da História, Spínola teve de aceitar a realização de modificações na sua estratégia colonial.

Neste sentido, em 26 de julho de 1974, Spínola promulgou uma nova Lei Constitucional, a lei n. ${ }^{\circ}$ 7/74, que reconheceu "o direito à autodeterminação, com todas as suas consequências, incluindo a aceitação da independência dos territórios ultramarinos". Da mesma forma, o projeto federalista foi posto de parte. Mas o Presidente da República ainda tentou chamar a si a condução do processo de descolonização de Angola, que era a colónia que tinha o maior número de brancos e a que estava mais bem controlada do ponto de vista militar, uma vez que as guerrilhas ainda em luta (MPLA e FNLA) estavam muito enfraquecidas. Mas o malogro da "Manifestação da Maioria Silenciosa", em 28 de setembro de 1974, convocada para reafirmar a supremacia política do Presidente da República, ditou o afastamento de Spínola da Presidência, em 30 de setembro de 1974. O General Costa Gomes assumiu então o lugar de Presidente da República ${ }^{17}$.

Claramente, a evolução da situação política metropolitana condicionou largamente o processo de descolonização. Vejamos então em maior detalhe a evolução do processo, primeiro em Moçambique, por uma questão cronológica, e depois em Angola.

\section{Moçambique}

O 25 de Abril suscitou uma grande efervescência política na sociedade moçambicana, em especial entre a população branca que acompanhou o desenrolar da revolução com curiosidade, mas também com receio pelo seu futuro

${ }^{17}$ Public Record Office (PRO, Londres), FCO 9/2059, Change of Government in Portugal, October 1974. 
no território ${ }^{18}$. Rapidamente surgiu um número elevado de partidos políticos, com posições divergentes relativamente à questão da independência. De facto, o novo poder revolucionário permitiu a constituição de formações partidárias, quer entre a população africana, quer entre a minoria branca. Entre a população africana teve um certo relevo o Grupo Unido de Moçambique (GUMO), cuja liderança era multirracial, e o Comité Revolucionário de Moçambique (Coremo), este último com uma existência anterior de tipo guerrilheiro. Entre a minoria branca, as formações politicamente mais significativas foram: o movimento dos Democratas de Moçambique, que reivindicou uma "total identificação ideológica com a Frelimo"; a Convergência Democrática de Moçambique, que defendeu a instituição de um regime parlamentar de inspiração social-democrata e, como tal, se opôs a qualquer tipo de ditadura ou regime de partido único; e a Frente Independente de Convergência Ocidental (FICO), que foi uma organização mais conservadora, anti-frelimista, cujo principal objetivo era garantir a continuidade da hegemonia europeia no território ${ }^{19}$.

No entanto, aquele que era considerado o líder mais destacado da comunidade branca, o engenheiro Jorge Jardim, político e empresário sediado na Beira, foi coibido de desenvolver atividades políticas. Antes do 25 de Abril, mais propriamente em setembro de 1973, Jorge Jardim tinha negociado com a Frelimo - por intermédio do Presidente Kaunda, da Zâmbia - uma espécie de acordo de princípios para a independência de Moçambique. Denominado de Programa de Lusaka, esse acordo nunca foi aceite por Marcelo Caetano e, a seguir à revolução metropolitana, foi renegado pela Frelimo. Impedido pelo poder revolucionário de viver em Moçambique, Jardim permaneceu inicialmente na metrópole como conselheiro do General Spínola. Mas, perante a emissão de um mandato de captura, fugiu para Espanha e depois para a África Austral, onde permaneceu em constante movimento entre o Malawi, a Suazilândia e a África do $\mathrm{Sul}^{20}$.

Neste contexto, o movimento que teve maior impacto político no processo de descolonização foi o dos Democratas de Moçambique. Com a conivência das estruturas locais do MFA, os Democratas conseguiram ocupar posições chave na administração colonial. Assim, um dos seus líderes mais destacados

${ }^{18}$ Notícias, n. ${ }^{\circ} 16.122,28$ de Abril de 1974, p. 1 e 5.

${ }^{19}$ Fernando Tavares Pimenta, "La decolonizzazione e l'indipendenza del Mozambico: coloni bianchi e movimenti nazionalisti”, Storicamente. Laboratorio di Storia, 12, n. ${ }^{\circ}$ 26, (2016), p. 1-38.

${ }^{20}$ PRO, FCO 9/2065, Relations Between Portugal and Africa, 1974 (British High Commission, Blantyre, 31/07/1974). Cf. Jorge Jardim, Moçambique terra queimada, Lisboa, Intervenção, 1976, p. 91-135. 
- o advogado António Almeida Santos - foi nomeado Ministro da Coordenação Interterritorial ${ }^{21}$ e outro dos seus dirigentes - o advogado Soares de Melo foi indigitado Governador-Geral de Moçambique. Os Democratas também conseguiram controlar os principais meios de informação, em especial a imprensa da capital e a Rádio Clube de Moçambique. O controlo do aparelho do Estado colonial e dos meios de informação possibilitou-lhes levar a cabo uma intensa campanha política a favor da Frelimo ${ }^{22}$.

No entanto, o seu discurso radical, de crítica severa ao capitalismo e com laivos de marxismo, bem como a sua recusa em reconhecer a legitimidade de outras forças políticas que não a Frelimo, acabou por assustar a população branca. De facto, os Democratas procederam à demonização política de todos os que se opunham à entrega do poder em regime de monopólio à Frelimo ${ }^{23}$. Todos os que exprimiam posições divergentes foram classificados de "colonial-fascistas":

"Só aos colonial-fascistas, com efeito, a não transferência de poderes para a Frente de Libertação de Moçambique interessa. E porque assim é, não me cansarei de lançar este apelo: O Poder para a Frelimo! O Poder para a Frelimo! O Poder para a Frelimo!"24.

Os Democratas contaram com o apoio do MFA para neutralizar os partidos rivais. Foi o caso da Convergência Democrática, que denunciou o perigo da instalação de uma ditadura de partido único caso o poder fosse transmitido exclusivamente para a Frelimo. Assim, a 28 de julho de 1974, na sequência duma reunião com a Comissão Coordenadora do MFA, a Convergência Democrática anunciou a suspensão das suas atividades, não sem antes denunciar o extremismo de quem tinha "fugido à discussão dos problemas". Num derradeiro comunicado à população moçambicana, a Convergência Democrática denunciou a existência de "controlo ideológico" da imprensa e da rádio por parte de grupos políticos interessados em promover sistematicamente a imagem da Frelimo e em negar e denegrir outros pontos de vista ${ }^{25}$.

${ }^{21}$ O Ministério da Coordenação Interterritorial sucedeu ao Ministério do Ultramar, herdando a sua estrutura político-administrativa. Cf. António Almeida Santos, 15 meses no governo ao serviço da descolonização, Lisboa, Asa, 1975.

${ }^{22}$ Fernando Tavares Pimenta, "La decolonizzazione...", cit., p. 16-19 e 27-28.

${ }^{23}$ Notícias, n. ${ }^{\circ} 16.209,28$ de Julho de 1974, p. 1 e 5.

${ }^{24}$ Notícias, n. ${ }^{\circ} 16.232,21$ de Agosto de 1974, p. 12.

${ }^{25}$ Notícias, n. ${ }^{\circ} 16.210,29$ de Julho de 1974, p. 5. 
Neste sentido, os Democratas de Moçambique, que afirmavam ter por objetivo preparar a minoria branca para a independência, canalizando o seu apoio para a Frelimo, acabaram por ter uma ação contraproducente, uma vez que alienaram as eventuais simpatias dos brancos, ao mesmo tempo que geraram fortes tensões no seio da comunidade.

Para além disso, a continuação da luta armada por parte da Frelimo, após o 25 de Abril, teve um impacto negativo na "psicologia" da maioria da população branca, acentuando os receios de eventuais retorsões depois da independência. Com efeito, a 3 de maio de 1974, a Frelimo decidiu aumentar a intensidade da luta armada contra a tropa portuguesa, de forma a explorar o ambiente de confusão gerado pelo golpe em Portugal. A Frelimo pretendia assim redobrar a pressão militar e psicológica sobre o lado português, de modo a entrar numa posição de força em eventuais negociações ${ }^{26}$. A Frelimo rejeitou também a ideia de constituição de uma federação com Portugal e recusou a participação de outras forças políticas no processo de independência, reivindicando a exclusividade da representação política do povo moçambicano ${ }^{27}$. Nas primeiras conversações havidas entre representantes portugueses e da Frelimo, em Lusaka, em 5/6 de junho de 1974, Samora Machel apresentou ao Ministro dos Negócios Estrangeiros de Portugal, Mário Soares, as três condições essenciais para o estabelecimento de um cessar-fogo: $1 .^{\circ}$ ) o reconhecimento do direito à independência imediata de Moçambique; $2^{\circ}{ }^{\circ}$ ) o reconhecimento da Frelimo como única legítima representante do povo moçambicano; $3 .^{\circ}$ ) a transferência do poder para as mãos da Frelimo ${ }^{28}$.

As reivindicações frelimistas não foram bem acolhidas por Spínola, mas foram aceites pelo MFA. Para o MFA, o mais importante era colocar um ponto final na guerra, mesmo à custa de entregar o país de "mão beijada" à Frelimo. Assim, a 1 de julho de 1974, a Comissão Coordenadora do MFA em Moçambique exigiu a realização de conversações com a Frelimo e, dez dias depois, recomendou o reconhecimento da Frelimo como o mais válido representante do povo de Moçambique. A 23 de julho, o Governador-Geral de Moçambique informava Lisboa que as Comissões do MFA de Tete e de Cabo Delgado ${ }^{29}$ tinham emitido um ultimato no qual ameaçavam declarar unilateralmente o cessar-fogo caso o governo português não o tivesse negociado até ao final do mês ${ }^{30}$. Estas pressões tiveram uma influência significativa sobre

\footnotetext{
${ }^{26}$ Norrie MacQueen, A Descolonização..., cit., p. 159-160.

${ }^{27}$ Notícias, n. ${ }^{0} 16.123,29$ de Abril de 1974, p. 1.

${ }^{28}$ Norrie MacQueen, A Descolonização..., cit., p. 164-167.

${ }^{29}$ Ao longo do texto, usamos a toponímia em voga na fase final do período colonial.

${ }^{30}$ Norrie MacQueen, A Descolonização..., cit., p. 161.
} 
o processo político português, tendo contribuído para a promulgação da já referida Lei Constitucional n. ${ }^{\circ} 7 / 74$, a qual abriu as portas à independência das colónias. Daí que novas rondas negociais entre Portugal e a Frelimo tenham tido lugar logo a partir de 30 de julho de 1974, tendo o Estado Português cedido às pretensões da Frelimo.

Por outro lado, os receios da minoria branca foram agravados pelo ambiente de crispação política e social nas principais cidades. Uma onda de greves, de manifestações e de protestos varreu o território, o que teve graves repercussões na economia e até no abastecimento de géneros de primeira necessidade às populações. $\mathrm{O}$ crime e a violência contra pessoas e bens cresceram de forma exponencial. Grupos de bandoleiros espalharam o pânico nas zonas rurais do centro e do norte de Moçambique, causando numerosas vítimas entre negros, brancos, mestiços e indianos. Paralelamente, certas unidades militares portuguesas começaram a negociar acordos separados de cessar-fogo com os guerrilheiros, nomeadamente em Cabo Delgado e no Tete. Aliás, a guarnição militar de Omar, na fronteira com a Tanzânia, rendeu-se à Frelimo, tendo os soldados portugueses sido feito prisioneiros e evacuados para a Tanzânia. Foi um acontecimento com uma enorme repercussão mediática e que baixou ainda mais o moral da população branca ${ }^{31}$.

O êxodo dos brancos teve início em agosto de 1974, na sequência de uma tentativa de "limpeza étnica" por parte de grupos de africanos armados contra as minorias branca e indiana na região compreendida entre Quelimane e António Enes e, duma forma geral, na zona de Nampula. Ocorreram então ataques a povoações e a famílias brancas indefesas por parte desses grupos armados. A Frelimo negou qualquer envolvimento nos acontecimentos e nunca se conseguiu apurar com exatidão quem esteve por detrás dessa “onda de violência anti-branca". Mas o facto é que o medo se apossou da população branca, de tal forma que, todas as semanas, estavam a sair da colónia cerca de mil brancos ${ }^{32}$.

Esta situação agravou-se em setembro de 1974, na sequência da assinatura do acordo de independência, em Lusaka, na Zâmbia. Assinado a 7 de setembro, o Acordo de Lusaka estabeleceu o reconhecimento português da independência de Moçambique e a transferência de poderes exclusivamente para as mãos da Frelimo, marcando a data da independência para 25 de junho de 1975. O Acordo definiu também a constituição de um Governo de Transição, formado por seis

${ }^{31}$ Idem, p. 161.

${ }^{32}$ Notícias, n. ${ }^{\circ}$ 16.222, 10 de Agosto de 1974, p. 1; Notícias, n. ${ }^{\circ}$ 16.225, 13 de Agosto de 1974, p. 1-2; Noticias, n. ${ }^{\circ} 16.227,15$ de Agosto de 1974, p. 1. 
ministros nomeados pela Frelimo e três por Portugal. O Governo de Transição seria chefiado por um Primeiro-Ministro indicado pela Frelimo. Portugal nomearia um Alto-Comissário, mas que não teria qualquer autoridade direta sobre o Governo de Transição ${ }^{33}$. Por outro lado, o Acordo não salvaguardou os direitos da minoria branca, nem sequer o direito à nacionalidade moçambicana. De facto, muitas questões ficaram por resolver, entre as quais os direitos de propriedade e a segurança dos cidadãos portugueses residentes em Moçambique. Foram excluídas do processo de independência e tornadas ilegais todas as outras forças políticas, preparando assim o terreno para a criação dum regime de partido único ${ }^{34}$. Tudo isto contribuiu para o aumento da desconfiança e da incerteza no futuro da maioria dos brancos, que julgaram não ter lugar no país depois da independência.

Neste contexto, o Acordo de Lusaka provocou uma reação imediata das forças políticas excluídas do processo de descolonização, nomeadamente da FICO e de alguns movimentos políticos formados por negros, como por exemplo o Partido de Coligação Nacional, que resultara da fusão do Coremo e do GUMO. Dirigentes políticos brancos - Gomes dos Santos, Hugo Velez Grilo, Gonçalo Mesquitela - e negros - Joana Simião, Uria Simango, Kawandame, Gumane juntaram-se numa única plataforma política para impedir a aplicação do Acordo, o Movimento Moçambique Livre (MML). A este se associou uma organização paramilitar denominada "Dragões da Morte". O MML desencadeou, no próprio dia da assinatura do Acordo, uma rebelião em Lourenço Marques (Maputo), ocupando a Rádio Clube de Moçambique e, momentaneamente, o aeroporto. O MML conseguiu mobilizar centenas de manifestantes que desfilaram nas ruas da capital a favor do movimento. Através da Rádio Clube, batizada Rádio Liberdade, os rebeldes apelaram à intervenção sul-africana, cujas tropas estavam estacionadas na fronteira, a escassos quilómetros de Lourenço Marques. $\mathrm{Na}$ Beira e em Vila Pery também houve manifestações de apoio aos insurretos. Jorge Jardim, então em Johannesburg, era considerado o líder dos rebeldes ${ }^{35}$.

Do lado português houve inicialmente alguma reticência em atuar contra a rebelião. De facto, a polícia e as forças militares permaneceram "indiferentes" perante o desenrolar dos acontecimentos, abstendo-se de intervir a favor ou

${ }^{33}$ Luís Moita, "Não há uma mas várias descolonizações", in Associação 25 de Abril, Seminário 25 de Abril. 10 anos depois, Lisboa, Fundação Calouste Gulbenkian, 1984, p. 289.

${ }^{34}$ AA.VV., "O acordo de Lusaka inconstitucional e antidemocrático não defende os interesses de Portugal e dos povos de Moçambique", Jornal Português de Economia \& Finanças, n. ${ }^{\circ} 325$, de 16 a 31 de Dezembro de 1974, p. 7-12.

${ }^{35}$ PRO, FCO 9/2503, Overseas Territories of Portugal, 1974. Cf. Jorge Jardim, Moçambique..., cit., p. 347-354. 
contra os rebeldes. E o Presidente da República, General António de Spínola, optou por enviar delegados para conversar com os líderes da rebelião. Mas a situação política alterou-se rapidamente a desfavor dos rebeldes devido à ação do MFA e do General Costa Gomes. Assim, em 9 de setembro de 1974, Spínola, sob pressão do MFA, ratificou o Acordo de Lusaka, o que retirou aos insurretos qualquer esperança de apoio da parte do Presidente. Os sul-africanos também optaram por não intervir militarmente em Moçambique, oferecendo apenas asilo político aos revoltosos. Sem o apoio de verdadeiras forças militares, a rebelião estava condenada ao fracasso. No dia 11 de setembro, por ordem direta do General Costa Gomes, tropas paraquedistas portuguesas, provenientes do norte de Moçambique, colocaram um ponto final na rebelião, que provocou um número considerável de mortos e de feridos ${ }^{36}$.

De facto, durante a revolta, grupos de extremistas brancos efetuaram raides aos subúrbios pobres da capital, disparando de forma indiscriminada sobre a população africana, com o objetivo talvez de a amedrontar e causando feridos e mortos. Mas estes ataques tiveram precisamente o efeito oposto, pois espoletou a violenta reação de milhares de populares negros que marcharam sobre a "cidade de cimento", armados de catanas, paus, pedras e ferros, e "deixando um manto de destruição à sua passagem". A este respeito, Benedito Machava, com base em relatos de alguns africanos que participaram nos acontecimentos, descreve um quadro particularmente "chocante" da forma como foram chacinados os brancos pela multidão em fúria: brancos assassinados no interior das respetivas casas ou queimados vivos, dentro de automóveis, quando tentavam fugir; mulheres esquartejadas; cadáveres abandonados nas ruas; etc. Dominada a custo por intervenção de um grupo de nacionalistas moçambicanos (o "Grupo Galo", conotado com a Frelimo, mas não integrante da sua estrutura política), esta onda de violência provocou o terror entre a população branca de Lourenço Marques, conduzindo à saída apressada de milhares de brancos para a África do Sul e a Rodésia ${ }^{37}$.

Embora de forma mais contida, a violência racial continuou nas semanas seguintes, por meio de agressões, roubos e destruição de bens e propriedades de

\footnotetext{
${ }^{36}$ Sobre o 7 de Setembro veja-se: Ricardo de Saavedra, Aqui Moçambique Livre, Johannesburg, Livraria Moderna, 1975; Clotilde Mesquitela, Moçambique 7 de Setembro, Lisboa, A Rua, 1976; Fernando Couto, Moçambique 1974. O fim do Império e o nascimento da nação, Lisboa, Caminho, 2011; Ribeiro Cardoso, O Fim do Império: Memórias de um Soldado Português. O 7 de Setembro de 1974 em Lourenço Marques, Lisboa, Caminho, 2014.

${ }^{37}$ Benedito Machava, "Galo amanheceu em Lourenço Marques: o 7 de Setembro e o verso da descolonização de Moçambique", Revista Crítica de Ciências Sociais, 106, Maio 2015, p. 72-75.
} 
brancos. E, em 21 de outubro de 1974, na sequência de uma rixa entre militares portugueses, ocorreu uma nova "explosão" de violência, de depredações e de homicídios que afetou sobretudo a população branca. Cinquenta brancos foram mortos e muitos mais foram agredidos por grupos de "marginais" antes que a ordem fosse restabelecida em Lourenço Marques ${ }^{38}$. Por consequência, mais alguns milhares de brancos fugiram para a África do Sul.

Estes acontecimentos impulsionaram o êxodo para Portugal de brancos, indianos, mestiços e até de alguns negros que não se identificavam com a Frelimo. A violência racial e o medo de retorsões foram claramente duas das principais causas do êxodo. De facto, durante anos, a propaganda salazarista incutiu o temor na população branca, descrevendo os guerrilheiros como um grupo de bandidos e de terroristas. Ora, a onda de violência que afetou muitos pontos do território moçambicano a partir de agosto de 1974, seguida dos distúrbios raciais espoletados pela rebelião de Lourenço Marques, não só confirmaram os receios da minoria branca, como acabaram por desencadear o seu êxodo. Por sua vez, os discursos radicais de Samora Machel, durante a sua "viagem triunfal" do Rovuma a Maputo, iniciada em maio de 1975, alarmaram ainda mais a minoria branca, que se sentiu hostilizada pelo máximo dirigente da Frelimo. Tal como sublinha a historiadora moçambicana Amélia Neves de Souto, os discursos de Machel "vão levar ao êxodo de milhares de portugueses pois não os tranquilizavam nem lhes davam qualquer segurança em relação ao seu próprio futuro no país" ${ }^{\prime 39}$.

Mas houve outros motivos que contribuíram para a saída da população branca, nomeadamente as políticas seguidas pela Frelimo logo após a independência. Com efeito, a adoção de políticas sociais e económicas de cariz marxista por parte do governo da Frelimo conduziu ao gradual afastamento de muitos brancos que inicialmente tinham permanecido no país. Com efeito, em julho de 1975, a Frelimo nacionalizou os serviços sociais e o sistema de ensino do país, o que gerou o ressentimento entre muitos brancos, que não aceitavam que os seus filhos tivessem uma educação permeada pela ideologia marxista da Frelimo. A Igreja Católica também foi duramente hostilizada pelo regime frelimista e os brancos, sendo na sua maioria católicos, foram duramente criticados pela sua

${ }^{38}$ Esta "explosão" de violência é descrita de forma detalhada em Carlos Camilo, "Moçambique. Os acontecimentos de 7 de Setembro e 21 de Outubro de 1974", in Associação 25 de Abril, Seminário 25 de Abril. 10 anos depois, Lisboa, Fundação Calouste Gulbenkian, 1984, p. 341-343. Cf. Norrie MacQueen, A Descolonização..., cit., p. 186-187.

${ }^{39}$ Amélia Neves de Souto, "Moçambique, descolonização e transição para a independência: herança e memória", in Fernando Rosas, Mário Machaqueiro, Pedro Aires Oliveira (ed.), O Adeus ao Império. 40 anos de descolonização portuguesa, Lisboa, Nova Vega, 2015, p. 150. 
filiação religiosa, inclusivamente nas escolas ${ }^{40}$. No plano económico, terras e habitações foram nacionalizadas em fevereiro de 1976, o que afugentou ainda mais a minoria branca, à exceção dos que se identificavam ideologicamente com os princípios defendidos pela Frelimo ${ }^{41}$.

Por outro lado, a instituição de um regime ditatorial, onde o "Estado era dirigido pelo partido único a todos os níveis e em todos os domínios", associada a uma excessiva centralização do poder nas mãos do Presidente da República (Samora Machel) geraram um ambiente de acentuada repressão política e social, tanto mais que a Frelimo tinha pretensões de dirigir e de modelar a sociedade moçambicana segundo um modelo revolucionário, porventura importado dos países comunistas, e que tinha em vista a "construção do homem novo". Assim, milhares de pessoas consideradas "reacionárias" ou simplesmente antissociais ("improdutivos, desempregados, prostitutas, mães-solteiras, ladrões, marginais, mas também intelectuais dissidentes") foram enviadas para "campos de reeducação", onde eram compelidas ao trabalho manual. Relativamente aos brancos, Amélia Neves de Souto salienta ainda que a Frelimo "excluiu camadas significativas da população europeia que se mostrava na altura, perante transformações tão profundas, e apesar de apoiar a independência

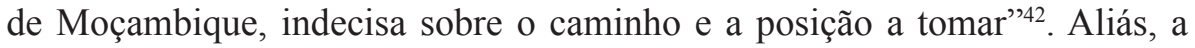
repressão da dissidência política afetou centenas de brancos, muitos deles com nacionalidade portuguesa. Em 1978, cerca de duzentos cidadãos portugueses estariam encarcerados sem julgamento nas prisões moçambicanas, havendo lugar a execuções sob acusação de atividades rebeldes ${ }^{43}$. Neste sentido, o regime ditatorial de inspiração marxista imposto pela Frelimo afugentou os restos da comunidade branca, tornando claro que não havia lugar para "colonos" no novo Moçambique independente.

\section{Angola}

Feita a análise da situação moçambicana, vejamos agora o caso angolano.

Tal como em Moçambique, o 25 de Abril suscitou em Angola o interesse de parte substancial da população branca que, de uma forma geral, exprimiu a

${ }^{40}$ Marta Vilar Rosales, "Retornos e recomeços: experiências construídas entre Moçambique e Portugal", in Fernando Rosas, Mário Machaqueiro, Pedro Aires Oliveira (ed.), O Adeus ao Império. 40 anos de descolonização portuguesa, Lisboa, Nova Vega, 2015, p. 217.

${ }^{41}$ Norrie MacQueen, A Descolonização..., cit., p. 271-272.

${ }^{42}$ Amélia Neves de Souto, Moçambique..., cit., p. 151-152.

${ }^{43}$ A. Rita-Ferreira, Moçambique..., cit., p. 121-169. 
sua adesão à nova situação política ${ }^{44}$. De resto, as expectativas eram elevadas relativamente à concretização das ideias enunciadas pelo General Spínola no seu livro Portugal e o Futuro. Com efeito, o protesto autonomista dos brancos angolanos tinha raízes profundas, remontando à 1. ${ }^{\text {a }}$ República. E, a partir da década de 1940, tinham surgido vários movimentos nacionalistas formados por brancos, dos quais o mais relevante foi a Frente de Unidade Angolana (FUA). Estes movimentos exigiam a independência de Angola no quadro duma espécie de Commonwealth Lusitana - a muito propalada Comunidade Lusíada. Ideia que estava em parte subjacente ao projeto federalista de Spínola. Por outro lado, a minoria branca dava sinais de confiança no seu futuro no país, não só devido à sua demografia em constante incremento, mas sobretudo porque as guerrilhas africanas - FNLA, MPLA e UNITA - estavam muito enfraquecidas e divididas entre si e não pareciam constituir uma ameaça à sua permanência no território. Muitos acreditavam que Angola poderia ser um "novo Brasil", isto é, um país governado pelos descendentes dos colonos portugueses, brancos e mestiços, com a colaboração das emergentes classes médias negras que aliás aparentavam não estar interessadas no revolucionarismo das guerrilhas ${ }^{45}$.

Logo após o 25 de Abril de 1974, o Estado Português restabeleceu as liberdades de expressão e de associação política, o que permitiu a formação e a legalização de partidos. Houve então uma verdadeira "explosão de partidos políticos", alguns formados por negros, outros por brancos e mestiços. Podemos agrupar estes últimos em dois conjuntos. Por um lado, os movimentos democráticos, criados pelos sectores intelectuais da antiga oposição democrática ao Estado Novo, que defendiam a negociação imediata da independência com as guerrilhas e apoiavam o MPLA. O principal movimento democrático estava sediado em Luanda e assumiu a designação de Movimento Democrático de Angola (MDA). Existiam movimentos democráticos mais pequenos em Benguela, Nova Lisboa (Huambo), Lobito, Sá da Bandeira (Lubango), Bié,

\footnotetext{
${ }^{44}$ A análise da imprensa colonial, nomeadamente do jornal A Província de Angola, permite aferir o impacto da revolução metropolitana na sociedade angolana, em especial entre a minoria branca. Nas primeiras semanas subsequentes ao golpe militar, foram múltiplas as manifestações populares de apoio à Junta de Salvação Nacional. Essas manifestações envolveram sobretudo brancos e mestiços, mas também um número muito significativo de negros residentes nas principais zonas urbanas. Refira-se que a população de Benguela foi a primeira a reagir à queda da ditadura, com uma manifestação de regozijo, em 28 de abril de 1974. Cf. A Província de Angola, 28 de Abril de 1974, p. 2. Seguiram-se o Lobito e Luanda, com manifestações semelhantes, em 1 de maio de 1974. Cf. A Província de Angola, 3 de Maio de 1974, p. 1 e 4.

${ }^{45} \mathrm{Cf}$. Fernando Tavares Pimenta, Angola. Os Brancos e a Independência, Porto, Afrontamento, 2008.
} 
Uíge, Cela e $\mathrm{Cuba}^{46}$. Por outro lado, os partidos conservadores, suscitados por certos sectores das elites económicas, que defendiam o projeto federalista ou a independência em moldes neocoloniais. Entre estes, o mais significativo foi o Partido Cristão Democrático de Angola (PCDA), cujo principal mentor foi Joaquim Fernandes Vieira, Presidente da Associação Comercial de Luanda. O PCDA defendia uma "descolonização consensual", com base numa participação eleitoral ilimitada que definisse o futuro de Angola, e tinha como porta-bandeira a multirracialidade. À direita do PCDA, situava-se a Frente de Resistência Angolana (FRA), mais extremista e que pretendia obter pela força uma representação própria na mesa das negociações para a independência, mediante a realização de um golpe secessionista, à maneira rodesiana ${ }^{47}$.

Num plano político completamente diferente situou-se a Frente de Unidade Angolana (FUA), cuja primeira fundação datava de 1961, mas que tinha sido duramente reprimida pela ditadura, para além de ter sido hostilizada pelo MPLA e pela FNLA. Em 1974, a FUA foi reativada pelo engenheiro Fernando Falcão, o seu primeiro presidente e um importante empresário branco do Lobito. A FUA tinha por objetivo obter a unidade do campo nacionalista de modo a garantir a construção de uma Angola independente e democrática, onde todos os angolanos tivessem lugar. Em termos programáticos, a FUA entendia que o processo de descolonização deveria passar pela formação de um governo provisório de coligação, a promulgação da lei eleitoral, a eleição duma Assembleia Constituinte com ampla participação dos partidos existentes, a promulgação e referendo da Constituição Política de Angola e a eleição do Chefe de Estado, por sufrágio direto e universal, após a qual se faria a transmissão de poderes para o novo Estado independente ${ }^{48}$.

À excepção dos movimentos democráticos, que reivindicavam uma identificação com o MPLA, os demais movimentos formados por brancos tiveram o apoio político do General Spínola. Efetivamente, mesmo depois da promulgação da Lei Constitucional $n .^{\circ}$ 7/74, Spínola continuou a acalentar as pretensões da minoria branca, tendo apresentado um plano de descolonização de Angola - com a duração de três anos - em 9 de agosto de 1974. Este plano consistia na realização dum cessar-fogo com as guerrilhas e a constituição de um governo provisório de coligação que representasse "todos os movimentos de libertação, em paralelo com os agrupamentos étnicos mais expressivos

${ }^{46}$ Instituto Arquivos Nacionais/Torre do Tombo (Lisboa), Arquivo PIDE/DGS, Delegação de Angola, Eugénio Bento Ferreira, Processo 53686, 8912.

${ }^{47}$ PRO, FCO 45/1504, Political Situation in Angola, 1974.

${ }^{48}$ A Província de Angola, 2 de Setembro de 1974, p. 5. 
do Estado de Angola", incluindo a "etnia branca". Ao governo de coligação competiria elaborar uma lei eleitoral, que garantisse a livre expressão de toda a população de Angola, e proceder ao recenseamento eleitoral na base de "um homem um voto". O governo provisório deveria também realizar, no prazo de dois anos, a eleição duma Assembleia Constituinte por sufrágio universal, direto e secreto, à qual competiria a elaboração da Constituição do Estado Angolano. Aprovada a Constituição, proceder-se-ia a novas eleições, das quais resultaria a formação de uma Assembleia Legislativa e de um Governo representativo da "vontade soberana do povo de Angola". O plano de Spínola previa ainda o envolvimento das Nações Unidas, nomeadamente através do envio de observadores internacionais aos "actos de consulta popular" ${ }^{49}$. Desta forma, Spínola pretendia assegurar o carácter democrático do processo de descolonização e criar as condições para a permanência dos brancos no país, garantindo-lhes uma representação no governo provisório.

No entanto, o plano spinolista foi recusado pelo MPLA e pela FNLA, que não aceitaram a participação dos movimentos políticos não armados, incluindo a FUA, no processo de independência. MPLA e FNLA reclamavam uma legitimidade política acrescida - relativamente aos movimentos aparecidos depois do 25 de Abril - pelo facto de terem conduzido a luta armada contra o colonialismo durante mais de uma década. Por isso, decidiram continuar a guerra contra os portugueses. Assim sendo, só a UNITA se mostrou disponível em negociar com Portugal, tendo assinado as já mencionadas tréguas em junho de 1974.

Não era porém a reduzida capacidade bélica das guerrilhas que preocupava a administração colonial, mas sim o ambiente de grande tensão social e política que afetava os bairros pobres - os musseques - de Luanda. Na verdade, os musseques - onde também viviam muitos "brancos pobres" - concentravam uma boa dose de tensão social acumulada. Após o 25 de Abril de 1974, com o abrandamento da vigilância policial, os contrastes sociais aumentaram significativamente, assumindo contornos raciais. Em 11 de julho de 1974, a situação conheceu um agravamento após o assassinato de um taxista branco no bairro da Cuca. O homicídio provocou a reação dos sectores mais extremistas da minoria branca, registando-se um conjunto de agressões à população negra dos musseques, que produziram um número elevado de mortos. Estas agressões provocaram a reação violenta da maioria negra, que saqueou as cantinas

\footnotetext{
${ }^{49}$ A Província de Angola, 10 de Agosto de 1974, p. 1-2.
} 
pertencentes aos brancos (e aos imigrantes cabo-verdianos). Foi o início duma onda de violência racial que se prolongou nos meses seguintes ${ }^{50}$.

Por outro lado, o MFA, que inicialmente estava mal organizado no território, foi adquirindo um peso cada vez maior no processo político. E, tal como em Moçambique, o MFA estava interessado numa descolonização rápida, mediante a entrega do poder diretamente às guerrilhas. A nomeação de Rosa Coutinho, um militar de esquerda, próximo do PCP, para Presidente da Junta Governativa de Angola, em finais de julho de 1974, fez pender a balança para o lado do $\mathrm{MFA}^{51}$. Assim, em 18 de setembro de 1974, num plenário realizado no Palácio de Governo de Luanda, cerca de quinhentos oficiais portugueses decidiram que o processo de descolonização só deveria ter em consideração "as forças políticas verdadeiramente representativas do povo angolano", ou seja os movimentos guerrilheiros que tinham combatido pela independência de Angola. Todas as outras forças políticas - FUA incluída - não passavam de "pseudo-partidos fantoches, formados por elementos reaccionários, servidores de interesses fascistas-colonialistas do antigo regime" ${ }^{52}$.

A FUA reagiu à decisão tomada nesse plenário, considerando que a moção desses militares constituía "uma grave ingerência na vida política de um Estado em formação", na medida em que os militares portugueses pretendiam impor diretrizes num processo político que aos angolanos caberia decidir ${ }^{53}$. Em resposta, a FUA foi acusada de encobrir os interesses colonialistas responsáveis pela exploração do povo angolano ${ }^{54}$.

Em 30 de setembro de 1974, a resignação do General Spínola à Presidência da República deitou por terra as expectativas da minoria branca. De facto, a partir desse momento, o Estado Português optou por negociar rapidamente a independência com os três principais movimentos guerrilheiros - e só com esses movimentos -, ou seja a FNLA, o MPLA e a UNITA. Provavelmente não havia da parte portuguesa uma intenção deliberada em "abandonar" a população branca, mas também não havia a vontade de continuar a combater para assegurar a sua participação no processo de independência. Assim sendo, a exclusão política dos brancos afigurava-se simplesmente como necessária

${ }^{50}$ Movimento Democrático de Angola, Massacres em Luanda, Lisboa, África Editora, 1974, p. 43-49.

${ }^{51}$ Pedro Pezarat Correia, Descolonização de Angola: a jóia da coroa do Império português, Lisboa, Inquérito, 1991.

${ }^{52}$ A Província de Angola, 22 de Setembro de 1974, p. 1 e 5; Idem, 23 de Setembro de 1974, p. 5 e 11.

${ }^{53}$ A Província de Angola, 22 de Setembro de 1974, p. 1 e 5.

${ }^{54}$ PRO, FCO 45/1504, Political Situation in Angola, 1974. 
para garantir a obtenção de um entendimento célere com as guerrilhas. E, de facto, foi possível obter a assinatura de um acordo de tréguas com a FNLA, em 10 de outubro, e com o MPLA, em 21 de outubro. As três guerrilhas foram então autorizadas a abrir delegações em Luanda, sendo que os guerrilheiros passaram a poder circular livremente - e armados - dentro do território angolano ${ }^{55}$.

Ao mesmo tempo, as autoridades portuguesas procederam à repressão dos partidos formados por brancos. O PCDA foi duramente afetado pela repressão, sob a acusação de que daria cobertura política à FRA, a qual estaria a organizar um golpe na colónia. Por ordem de Rosa Coutinho, foram efetuadas várias detenções de civis e de militares acusados de participar nessa alegada tentativa de golpe, que estaria previsto para 26 de outubro de 1974. Interpelado sobre o assunto pelo Cônsul Geral Britânico em Luanda, um membro da Junta Governativa de Angola afirmou que, se fosse necessário, as Forças Armadas estariam dispostas a abrir fogo sobre os brancos ${ }^{56}$.

A minoria branca ainda tentou resistir às determinações das autoridades, por via da realização de manifestações e de greves, das quais a mais saliente foi a greve dos camionistas em novembro de 1974. Esta greve paralisou a economia do país, isolando Luanda e as demais cidades das suas fontes de abastecimento. Na zona do Lobito, o comércio e a indústria paralisaram numa ação de apoio à greve, ao passo que foram cortadas as estradas que ligavam o Lobito ao Huambo e a Luanda. As entradas das principais localidades foram bloqueadas por piquetes. Na capital, a escassez de géneros alimentares provocou o recrudescimento dos incidentes e da violência, sobretudo nos musseques. Esta situação foi explorada em termos políticos por alguns dirigentes das associações económicas, que procuraram tirar partido do potencial reivindicativo da greve. Foi então apresentado um caderno de reivindicações, cujo objetivo era obrigar o governo a garantir a participação dos brancos no processo de independência ${ }^{57}$.

Mas a reação à greve foi vigorosa. Na imprensa, os camionistas foram acusados de sabotagem da economia e de serem instrumentos da "reacção branca". E as associações económicas foram classificadas de "inimigas" do povo angolano pelo MPLA. Por arrastamento, a minoria branca foi reduzida ao estatuto de camada reacionária da sociedade colonial ${ }^{58}$. Por sua vez,

\footnotetext{
${ }^{55}$ Fernando Tavares Pimenta, Angola ..., cit., p. 389-396.

${ }_{56}$ PRO, FCO 45/1504, Political Situation in Angola, 1974. Pompílio da Cruz, Angola: os vivos e os mortos, Lisboa, Intervenção, 1976, p. 199 e 201-203.

${ }^{57}$ A Província de Angola, 11 de Novembro de 1974, p. 3.

${ }^{58}$ A Província de Angola, 16 de Novembro de 1974, p. 1 e 11.
} 
Rosa Coutinho deu ordem de prisão aos principais responsáveis pela greve, inclusivamente ao Presidente da Associação Comercial de Luanda, Fernandes Vieira. Para o efeito, Rosa Coutinho teve o apoio do governo de Lisboa, que o elevou à condição de Alto-Comissário de Angola. O MFA também decidiu tomar uma posição veemente, ameaçando usar a força contra qualquer grupo que colocasse em causa as diretivas do Alto-Comissário ${ }^{59}$. Perante isto, os camionistas e os dirigentes das associações económicas recuaram nas suas posições. Tomou-se consciência de que ninguém em Angola tinha força suficiente para enfrentar abertamente as Forças Armadas Portuguesas ${ }^{60}$.

Neste contexto, em 30 de novembro de 1974, Rosa Coutinho anunciou a realização duma cimeira entre Portugal e os três movimentos armados com o objetivo de definir os moldes da independência. Não participariam representantes de quaisquer outras forças políticas ${ }^{61}$. A FUA acusou então o Alto-Comissário de "esquecer ou negar" as promessas feitas pela Junta de Salvação Nacional, que teriam garantido a participação de representantes da minoria branca no processo de independência. E, sobretudo, "esquecer ou negar" os princípios democráticos preconizados pelo 25 de Abril ${ }^{62}$. Com efeito, a FUA considerava inconcebível, em democracia, a ideia da marginalização no processo de independência de todas as forças políticas que não os três movimentos armados ${ }^{63}$. A FUA também alertou para o facto de as guerrilhas continuarem a enquadrar elementos nos seus exércitos como que preparando um regresso à guerra ${ }^{64}$. A FUA exprimia assim a sua preocupação pela provável eclosão de uma guerra civil entre os três movimentos logo que o poder lhes fosse transferido em regime de exclusividade ${ }^{65}$.

No entanto, Portugal optou por ignorar os avisos da FUA, tendo assinado o Acordo de independência com as três guerrilhas no Alvor, em 15 de janeiro de 1975. O Acordo reconheceu a FNLA, o MPLA e a UNITA "como os únicos e legítimos representantes do povo angolano", de modo que todas as outras forças políticas deixaram de ter legitimidade política para continuar a existir. Como

\footnotetext{
${ }^{59}$ A Província de Angola, 28 de Novembro de 1974, p. 5.

${ }^{60}$ A Província de Angola, 30 de Novembro de 1974, p. 1.

${ }^{61}$ A Província de Angola, 30 de Novembro de 1974, p. 2.

${ }^{62}$ A Província de Angola, 3 de Dezembro de 1974, p. 3 e 5.

${ }^{63}$ A Província de Angola, 7 de Dezembro de 1974, p. 1-2; Idem, 12 de Dezembro de 1974,

${ }^{64}$ A Província de Angola, 13 de Dezembro de 1974, p. 9 e 14.

${ }^{65}$ A Província de Angola, 10 de Janeiro de 1974, p. 2.
} p. 9. 
tal, deveriam dissolver-se ou integrar-se num dos três movimentos armados ${ }^{66}$. O poder seria transmitido em regime de exclusividade para as três guerrilhas, tendo sido estabelecida a criação de um Governo de Transição, liderado por um colégio presidencial de três membros, um em representação de cada um dos três movimentos. Ao Governo de Transição caberia organizar eleições para uma Assembleia Constituinte. Mas às eleições só seriam admitidos os candidatos dos três movimentos. Portugal nomearia um Alto-Comissário, mas que não teria poder sobre o Governo de Transição. A data da independência foi marcada para 11 de novembro de $1975^{67}$.

Neste sentido, o Acordo do Alvor não estabeleceu as condições necessárias para que a população angolana pudesse decidir sobre o seu próprio futuro, no quadro de um multipartidarismo amplo e não apenas restrito a três movimentos. Além disso, ao excluir as demais forças políticas do processo de independência, cada uma das três guerrilhas ficou com as "mãos livres" para preparar sozinha a tomada do poder, em detrimento dos outros dois parceiros. Por outro lado, o Acordo não tentou assegurar a permanência dos brancos no país, na medida em que os signatários optaram por ignorar o problema do estatuto jurídico e político dessa minoria, dois terços da qual nascida fora do país, que pela sua condição de população colonizadora se colocava num plano político necessariamente diferente da maioria colonizada. A comunidade branca ficou portanto numa situação de grande vulnerabilidade, ficando à mercê da boa vontade dos guerrilheiros. Estavam assim criadas as condições para o seu êxodo.

Neste contexto, a guerra civil eclodiu poucas semanas depois da assinatura do Acordo do Alvor. A partir de 24 de março de 1975, o MPLA e a FNLA envolveram-se em violentos confrontos em Luanda. As reações das autoridades foram pouco veementes. O Alto-Comissário, General Silva Cardoso, exigiu o fim do conflito, mas por alguma razão não utilizou o potencial militar que ainda tinha à sua disposição para colocar um ponto final na violência ${ }^{68}$. Os confrontos continuaram e alargaram-se a outros pontos do país. A UNITA entrou no conflito em junho de 1975, depois de ter sido expulsa da capital pelo MPLA. A FNLA também foi derrotada em Luanda, retirando-se para norte. Em agosto de 1975, a FNLA e a UNITA fizeram uma aliança em função anti-MPLA. A guerra civil depressa se transformou num conflito internacional entre potências adversas

${ }^{66}$ O MDA integrou-se no MPLA em 9 de Março de 1975, ao passo que a FUA foi obrigada a dissolver-se. Cf. Fernando Tavares Pimenta, Angola ..., cit., p. 410-426.

${ }^{67}$ A Província de Angola, 16 de Janeiro de 1975, p. 1-2.

${ }^{68}$ General Silva Cardoso, Angola: anatomia de uma tragédia, Lisboa, Oficina do Livro, 2001. 
no contexto da Guerra Fria. Em Luanda, o MPLA recebeu o apoio maciço de tropas cubanas e o apoio logístico da URSS. No norte de Angola, a FNLA foi apoiada por tropas zairenses e por mercenários de vários países europeus, bem como por instrutores militares dos EUA e da China. No sul de Angola, a UNITA foi apoiada por tropas sul-africanas ${ }^{69}$.

Simultaneamente, a minoria branca passou a ser objeto de vexações, de violências e mesmo de ataques por parte de grupos armados. Portanto, os brancos, que tinham sido impedidos de participar através dos seus próprios representantes no processo de independência, eram agora "constrangidos pelas circunstâncias" a abandonar o país. A violência dos combates acelerou a fuga maciça da população branca. A imprensa angolana descreveu bem os "motivos" do êxodo:

"Essa gente vai porque os privilégios secaram? Não vão por causa disso, não senhor! Umas partem porque se sentem traídas, outras porque se imaginavam na sua terra e agora muitos afirmam e negam, simultaneamente, esse direito; porque se viram de um dia para o outro na pele de tolerados; porque sentiram na carne e no espírito o que é a espoliação, o assassinato, o roubo, a violação; porque o clima de anarquia se alastra a todo o território; abandonam os seus postos não para sabotar a economia, mas porque não têm nas 24 horas do dia homens armados a rodeá-los para garantir, não a prepotência, mas simplesmente o seu trabalho e a defesa das suas vidas" ${ }^{\prime 70}$.

Face a isto, as autoridades portuguesas ${ }^{71}$ decidiram evacuar por via aérea os "portugueses" residentes na colónia, ou seja os brancos e determinadas franjas da população mestiça que reentravam nos critérios estipulados pela Lei da Nacionalidade de 1975 (Decreto-lei n. ${ }^{\circ}$ 308-A de 24 de Junho de 1975). A evacuação foi realizada pelos aeroportos de Luanda, Nova Lisboa e Sá da Bandeira, sendo a população deslocada escoltada pela tropa portuguesa até

${ }^{69}$ Cf. Witney W. Schneidman, Confronto em África. Washington e a queda do Império Colonial Português, Lisboa, Tribuna, 2005.

${ }^{70}$ A Província de Angola, 2 de Agosto de 1975, p. 1.

${ }^{71}$ A ponte aérea foi em larga medida organizada pelo tenente-coronel António Gonçalves Ribeiro, Secretário-Geral do Alto Comissariado em Angola, que para o efeito pressionou o Presidente da República, General Costa Gomes. Foram efetuados novecentos e cinco voos, envolvendo a TAP e companhias estrangeiras. Vários países colaboraram na ponte aérea, entre os quais o Brasil, os Estados Unidos da América, a França, a República Federal Alemã, a Noruega e a União Soviética. Cf. Isabel de Sousa Lima Junqueiro Barreto, Migrantes da Descolonização: portugueses e luso-angolanos no Brasil (1974-1977), Niterói (Tese apresentada ao Programa de Pós-Graduação em História da Universidade Federal Fluminense), 2014, p. 77-101. Cf. Rita Garcia, S.O.S. Angola: os dias da ponte aérea, Alfragide, Oficina do Livro, 2011. 
aos locais de embarque, no meio de tiroteios e de violentos confrontos entre as forças em conflito. No sul de Angola, um número considerável de brancos decidiu atravessar a fronteira com a Namíbia, à espera duma resolução rápida do conflito. Nunca foi determinado o número exato de pessoas evacuadas no segundo semestre de 1975. Em 24 de setembro de 1975, o novo Alto-Comissário, Leonel Cardoso, declarou que era necessário "repatriar" cerca de trezentas mil pessoas para Portugal ${ }^{72}$. Nem todos eram brancos. Um número substancial de mestiços e de negros também abandonou o país com a ponte aérea, tanto mais que havia um conjunto considerável de famílias mistas ${ }^{73}$.

Neste sentido, a guerra civil espoletou o êxodo maciço dos brancos de Angola. Mas a guerra foi apenas o corolário de um complexo e atribulado processo de descolonização, que se saldou na exclusão política da população branca.

\section{Conclusão}

Neste contexto, o êxodo das minorias brancas das colónias portuguesas foi o resultado de um conjunto de condicionantes - entre as quais a violência racial - e de opções políticas que não tiveram em devida consideração as especificidades dessas minorias que, pela sua condição de estratos colonizadores, não se situavam no mesmo plano político das maiorias colonizadas. Assim, a forma como foi concretizado o processo de descolonização, por meio de acordos fechados entre Portugal e as guerrilhas africanas, sem a participação dos partidos formados por brancos e à custa da marginalização política das populações brancas, e a transferência dos poderes em regime de exclusividade para essas mesmas guerrilhas criaram as condições para o êxodo das minorias brancas. Abandonados pela potência colonial e despojados de qualquer poder de intervenção, os brancos viram-se na posição de meros tolerados - e muitas das vezes mal tolerados - pelos guerrilheiros. Além disso, os brancos tornaram-se no alvo dos ressentimentos de muitos africanos, ou seja numa espécie de bode expiatório das desigualdades, do racismo e das injustiças produzidas pelo colonialismo português. E os discursos de alguns dirigentes nacionalistas (por exemplo, de Samora Machel), no lugar de serenar os ânimos, contribuíram decisivamente para um extremar de posições, acentuando os receios da

${ }^{72}$ A Província de Angola, 24 de Setembro de 1975, p. 1.

${ }^{73}$ João dos Reis, Malandros. A evacuação aérea dos Portugueses de Angola, Queluz: Literal, [s. d.]; Rosa Coutinho, "Notas sobre a descolonização de Angola", in Associação 25 de Abril, Seminário 25 de Abril. Dez anos depois, Lisboa, Fundação Calouste Gulbenkian, 1984. 
população branca. Como tal, a eclosão de episódios de violência racial - no caso de Moçambique - e de uma sangrenta guerra civil - no caso de Angola -, associada ao medo de retorsões por parte das maiorias africanas, bem como a adoção de políticas marxistas contrárias aos interesses dos colonos, em especial no caso moçambicano, conduziram ao êxodo maciço das minorias brancas da ex-África Portuguesa. 